\title{
An Investigation of the Scale and Spread of Child Marriage in the Suburbs of Mashhad (Ismaeel-Abad Region), Focused on Causes, Factors, and Preventive Solutions
}

Una investigación de la escala y la propagación del matrimonio infantil en los suburbios de Mashhad (región de Ismaeel-Abad), centrada en causas, factores y soluciones preventivas

\section{Mahboobeh Tamizi}

Master Student, Department of Law, Mashhad Branch, Islamic Azad University, Mashhad, Iran ORCID ID: https://orcid.org/0000-0001-5396-117X

\section{Abbas Sheykholeslami}

Associate Professor, Department of Law, Mashhad Branch, Islamic Azad University, Mashhad, Iran ORCID ID: https://orcid.org/0000-0002-0224-9884 


\section{Summary}

The phenomenon of Child Marriage is referred to as a marriage or similar union between a child and an adult or another child under the age of eighteen. The causes of child marriage include: family relations, sexual discrimination, controlling sexual relationships and maintaining the dignity of the family, certain economic factors and other social and cultural factors as well. Among the effects of early marriage on children it can be pointed to divorce at young ages and its risks for girls, dropout, harming of children's sexual health and their fertilization rights an instance of which is early pregnancy putting both the mother's and infant's health at risk, sexual dissatisfaction, increased violence and exploitation, violation of child rights, and lack of ability to manage life affairs. Filed investigations on the factors of child marriage in the Ismaeel-Abad district of Mashhad show that the most important factors that promote child marriage in the investigated area include economic factors and social attitudes. In terms of solutions aimed at mitigating the rate of child marriage, fighting poverty, training families and promoting their awareness, empowering the youth, reviewing and amending the laws, and correcting the cultural procedures of selecting a spouse can be considered to be potentially effective.

Keywords: spouse child, growth, maturity of marriage, marginalization.

\section{Resumen}

El fenómeno del matrimonio infantil se conoce como matrimonio o unión similar entre un niño y un adulto u otro niño menor de dieciocho años. Las causas del matrimonio infantil incluyen: relaciones familiares, discriminación sexual, control de las relaciones sexuales y mantenimiento de la dignidad de la familia, ciertos factores económicos y también otros factores sociales y culturales. Entre los efectos del matrimonio precoz en los niños se pueden señalar el divorcio a edades tempranas y sus riesgos para las niñas, el abandono escolar, el daño a la salud sexual de los niños y sus derechos de fecundación, un ejemplo de lo cual es el embarazo precoz que pone en riesgo la salud tanto de la madre como del bebé., insatisfacción sexual, aumento de la violencia y la explotación, violación de los derechos del niño y falta de capacidad para manejar los asuntos de la vida. Las investigaciones archivadas sobre los factores del matrimonio infantil en el distrito Ismaeel-Abad de Mashhad muestran que los factores más importantes que promueven el matrimonio infantil en el área investigada incluyen factores económicos y actitudes sociales. En términos de soluciones destinadas a mitigar la tasa de matrimonio infantil, combatir la pobreza, capacitar a las familias y promover su conciencia, empoderar a los jóvenes, revisar y enmendar las leyes y corregir los procedimientos culturales de selección de cónyuge, puede considerarse potencialmente efectivo.

Palabras clave: Esposa hijo, crecimiento, madurez del matrimonio, marginación.

\section{Introduction}

Reviewing the history of child marriage legislation reveals that the legislators who drafted the civil code back in 1934, put the article 1041 of the civil code under the $2^{\text {nd }}$ chapter, by the title of "Physical eligibility for marriage" without taking the concept of puberty and puberty age into account; stating that girls under the age of fifteen and boys under the age of eighteen are not physically eligible for marriage, but under special circumstances and by the suggestion of the D.A and approval of a court, it would be possible for a thirteen year old girl and a fifteen year old boy to marry. In 1974, the article 23 of the law of family support was legislated to maintain that the minimum age for girls' and boys' marriage is respectively eighteen and twenty, while envisaging the possibility of marriage of girls under fifteen, conditional to exceptionality of the situation. In 1982, the legislators abandoned the condition of "Physical eligibility for marriage" and in an effort to follow the jurisprudence, established "puberty" in the article 1041 of the civil code; and amended the law so it would maintain: marriage before puberty is forbidden. However, in an 
additional note to the same article and following the popular jurisprudential opinion, child marriage before puberty was allowed conditional to the consent of the parents, dissolving the need for getting the D. A's or a court's permit. In this way, even children very young, such as girls and boys younger than nine and fifteen are allowed to marry if their parents are consentaneous.

In addition to the amendment of the article 1041 in 1991 which did not make essential change in the mentioned article, another change was made in the article by the expediency discernment council in 2002 which maintained that marriage of boys under fifteen and girls under thirteen not only requires the consent of the parents, but also is conditioned to court order. On this basis, children under the ages of thirteen and fifteen (even children younger than nine) can still get married, though conditioned to the consent of parents and a court order.

Researchers believe that there are several different factors that promote the phenomenon of child marriage, with the most important of them being poverty. Families usually receive certain amounts of money in return for marrying their daughter to a man. Therefore, when girls marry at young ages, not only they're no longer a burden on the family in terms of food, education, and clothing expenses, but also, they will cause materialistic and economic benefits for the family as well.

Among the consequences of child marriage, it can be pointed to early pregnancy, which is one of the most dangerous consequences of this phenomenon. Child brides may get pregnant prior to physical maturity, which puts both the mother and infant's life at risk of death. In addition, being deprived from education, loss of better chances and opportunities in life, elimination or marginalization of a certain portion of the society's manpower, and being trapped in the loop of poverty are among other consequences of child marriage.

Furthermore, child marriage faces the society with mothers who because of their own youngness are not eligible to nurture the next generations. Considering the fact that child marriage is commonly more prevalent among girls and that its negative consequences and damages usually target their population, therefore the present study's main emphasis is on the effects of child marriage on girls.

\section{Methodology}

The present study is a descriptive-survey research, the first step of conducting which included library studies (books and articles) relating to the field of investigation. Afterwards, a researcher made questionnaire was prepared and used as the main instrument of field studies, and ultimately, the SPSS software was used to analyze the findings and collected data.

\section{Topic One: Concepts}

\section{Word One: The Concept of Suburb}

By the suburbs it is referred to a part of a city in which residential buildings are run-down and equipment and facilities are worn-out, while the atmosphere is dominated by poor culture, mass separation of rural people from those living in cities and, isolation and seclusion as well.

\section{Word Two: The Concept of Suburbanism: its Characteristics and Consequences}

The concept of suburbanism has different meanings and names, but it usually refers to housings lacking primary humane services and needs. Seemingly the very first definition provided for suburbanism dates back to 1812 , when suburban areas were referred to as crowded areas prone to criminality. In between 1830s and 1840s, poor people used to live in such places. In the classic era, suburban areas were notorious zones different than other areas. At that time, reformists were usually agreed with Charles Bott, who defined suburban areas as mixtures of run-down buildings, high population density, poverty and, weakness. The moral aspects of this issue were important for the liberals of the $19^{\text {th }}$ century. In their view, the suburban areas were more than anything else, crowded areas filled with social residues, corruption and, unethical places. However, later on, the authors and scholars who worked on the issue of suburbanism abandoned the Victorian era accusations and came up with a classical definition for suburbanism. Their definition for suburban areas was: zones crawled with high population density and poverty, with plenty of unofficial housings, lack of equal access to clean running water and illegally occupied lands. 
Shrader (2004) reflects on the informality aspect of suburbanism as the result of existence of residents occupying the lands illegally but in a tolerable way.

\section{Word Three: The Concept of Child}

From the point of view of law, a child or a minor is someone not yet old enough to be physically and mentally ready for life. On the other hand, by child rights it is referred to rights born for children due to being juveniles. Therefore, those laws and rules that are enforceable independent of persons' age are not included in the domain of child rights.

The article one of the Convention on Child Rights defines child as follows:

By children (minors, underage people, or juveniles) it is referred to all under eighteen humans, unless the applicable law considers a younger puberty age for children.

\section{Word Four: The Concept of Child Marriage}

By child marriage, it is referred to a marriage or similar union between at least one under eighteen spouse and another. Both terms of "child" and "marriage" have taken different definitions in different societies. The international society refers to children as people under the age of eighteen, whereas, Iranian law considers that people reach maturity (puberty) before the age of eighteen.

\section{Topic Two: On the Causes of Child Marriage Word One: Family Relationships}

Even today, still in some areas of Africa and Asia, and for reasons such as strengthening familial relationships, making land, property, and other deals, and also in order to resolve familial and tribal disputes, people readily ignore children's rights as simple humans, forcing them to marry for mentioned reasons. For instance, in Pakistan, giving away girls (forcing them to marry others) is a common way of evading paying blood-money to victim families. Even in African countries such as Togo and Benin, girls are used as sex-slaves in a way that, they will be forced to serve their gods' priests with sexual services as an atonement for the sins and crimes of their relatives. In addition, they are deprived of any for of access to education and health-care.

\section{Word Two: Discrimination (Sexual Inequality)}

Different generations and cultures have their own false inequalities and discriminations depending on various factors including economic status, stratum, race, gender, disability, and religion. Such discriminations can tackle traditions or even laws that generally harm women at different ages by depriving them of their rights. In fact, such inequalities can promote early marriage, as it exists at raging rates in countries such as Nigeria and India; meaning that girls do not have any saying in their own marriage, sexual health or their reproductive rights.

\section{Word Three: Controlling Sexual Relationships and Maintaining the Family's Dignity}

in some cases, child marriage takes place according to the belief that it is a factor in controlling girls' sexual behaviors and reproductivity mainly because cultural and religious beliefs concerning virginity, chastity and, purity of girls are directly related to a family's dignity status. This means high levels of family influence on the marriage of children. In some rural societies, in order to keep the dignity of the family and mitigate the risk of occurrence of inappropriate sexual activities, as a girl experiences her first menstrual period the parents will keep her from going to the school in an attempt to control and maintain her sexual activity through restricting her. They also believe that in long-term, educating girls can leave a negative effect on their future roles as wives and mothers. In fact, such families feel like by being consent with marriage of their children, they are somehow guaranteeing their physical and sexual security through keeping their virginity.

\section{Word Four: Economic Factors}

Traditional and less-developed societies experience high rates of infant and child mortality. In fact, in such societies the survival of infants and children is dependent on the family's financial capability which determines the ability to flatten the needs of the family, including the children. 
On this basis, it can be stated that the main reason for child marriage is poverty, because as someone leaves the home, the rest of the family members will benefit from a higher share. This is why in countries located in the African Desert, it is obviously evident that poverty and other problems cause the families to force their children to marry at early ages. Even in some societies, men who do not have enough financial capability to marry a girl will abduct women and girls and expose them to violence and raping.

\section{Word Five: Social and Cultural Factors}

A girl's education is a strong determinant of early marriage. In countries where girls have a higher education, the rates of early marriage are lower considering that in general, rural societies experience higher rates of early marriage compared to urban societies.

On this basis, in majority of cases the customary and religious traditions include paying attention to the age of marriage, being an obedient wife, making a crowded family and etc. For example, regarding the phenomenon of child marriage, patriarchy means that the father plays a much bolder and more axial role in the marriage of the daughter, then the girl herself. In fact, in such societies the customary rules are dominant over national rules. On the other hand, what is perfectly evident to have roots in the culture and region's traditions is the child's education, which is also considered as an important factor determining girls' consent to marry. In this way, as a child's education level advances, their consent to early marriage recedes. In rural areas, the governing culture and dominant ways of live result in lower education levels for girls, meaning a higher rate of early marriage in these areas.

\section{Topic Three: On the Child Marriage with Respect to Iran's Jurisprudential Basics and Legal System \\ Word One: Discussing Jurists' Views on the Necessity of Growth and Maturity for Marriage Section One: Necessity of Growth for Marriage in the Views of Jurists}

The holy Quran uses the phrase "ultimate maturity", but interpreters do not hold consistent views on the definition of ultimate maturity, with some of them believing it refers to the act of nocturnal emission and puberty whereas, others believe it refers to mental perfection. Among these interpretations, some has even stressed out that the age of ultimate maturity is thirty.

Alameh-Tabatabaei believes that ultimate maturity occurs when physical strength meets rigidity and childness fades; this is the maturity and growth referred to by the verse six of the Sura of Nesa, and it pervasively commences at the age of eighteen.

Reviewing the verses and narratives makes it clear that "ultimate maturity" covers a wider area than mere sexual maturity, also entailing mental maturity and rigidity and perfection of physical strengths. However, a person's eligibility for financial occupancy is determinable by either of "ultimate maturity" or "matrimony and growth maturity".

\section{Section Two: Matrimony Maturity}

While elaborating on the testing of orphans in the course of surrendering properties to them, the Holy Quran uses the phrase "matrimony maturity". In this regard, one can also refer to the verse six of the Sura of Nesa, from the looks of which it seems that the criterion for maturity, is to meet a standard that allows girls and boys to marry. For boys, this standard is Nocturnal Emission whereas for girls it is Menstrual Cycle.

Interpretive books have considered matrimony maturity as equal to reaching an age when the capacity and readiness for marriage start appearing. The popular opinion among the jurists also maintains that the criterion for marriage competency is maturity, and based on certain narratives, for boys and girls it occurs at the ages of fifteen and nine, respectively. Some jurists have even claimed there is a consensus on this.

On this bases, Imamia jurists believe that reaching the natural maturity is sufficient for marriage. They even allow the marriage of underage (not mature) children conditional to the consent of the father, and back their opinion by referring to related narratives, especially those concerning the authority of terminating the marriage for the child after reaching maturity. However, some other jurists believe that such a marriage is only allowed conditional to consensus of jurists. Though, 
in spite of the mentioned narratives, any consensus backed by these narratives would be circumstantial, lacking validity.

\section{Word Two: One the Age of Marriage in Iran's Legal System}

After the victory of the Islamic Revolution and through the course of the first Islamic Council (Parliament) in 1982, the draft of "the bill regarding amendment of certain legal cases", amended the article 1041 of the civil code as follows: Marriage before maturity is forbidden. Annex: prematurity marriage is allowed conditional to the consent of parents and adherence to the expediency of the underage. By the annex to the article 1041 of the civil code, the article 1209 which referred to the age of eighteen was deleted and in return, the article 1210 was amended in a way that its annex 1 refers to maturity ages of fifteen and nine for boys and girls, respectively. In a later amendment in 1991, the article of interest was reformed to: pre-maturity marriage is valid conditional to the permission of the parents and adherence to the expediency of the underage. These changes made significant declination in marriage age, and although they were objected, in between 1982 and 2002 the ages of thirteen and nine have had been considered as the legally legitimate ages of marriage for boys and girls, respectively. In 2000, the parliament made yet another reviewing of the article 1041, but due to differences between the parliament and the guardian council and the fact that the guardian council believed this article was in contrast with Sharia (in other words, it was unlawful), the matter became the expediency discernment council's concern to determine its fate; however, no conclusion was reached until a renewed amendment for the article 1041 of the civil code was brought to the parliament in 2002.

In the mentioned amendment, the suggested marriage ages for girls and boys were respectively 14 and 17; while maintaining that marriage of children under these ages would only be legal if allowed by a court. Ultimately, once the amendment plan was reviewed by the judicial, legal, and cultural committees of the parliament, the ages of eighteen and fifteen have been determined as the legal marriage ages for boys and girls respectively. However, this enactment too was considered contrary to the Sharia by the guardian council.

Ultimately the issue was once again brought to the expediency discernment council, and so the article was enacted as follows:

"marriage of girls before the age of thirteen and boys before the age of fifteen is conditioned to permission of the parents, adherence to the expediency of the underage, and permission of a court as well".

With respect to Iran's legal system, we are faced with varying childness ages regarding different affairs. However, making underage marriage of girls (before thirteen) and boys (before fifteen) conditional to the permission of parents, adherence to the expediency of the underage, and permission of a court is an effort made in the legal system of Iran considering for the international conditions and the resulting temporal and geographic expediencies. Nevertheless, currently no necessity is felt to make any changes.

\section{Topic Four: Reviewing and Explaining the Existing Legal Solutions for Mitigation of Child Marriage}

Regarding the existing legal solutions aiming to mitigate child marriage, it can be stated that the law is a basic factor in controlling and shaping different social phenomena, and has the potential to create the contexts for promotion of a positive culture through the society. With a firm will combined with the knowledge that early marriage can create a chain of harm for children, one can try to enact laws that aim to increase the marriage age, or even tackle the reviewing of laws in terms of entailing individuals' mental maturity to enter a serious relationship; and so, mitigate the number of early marriages.

Regarding effective solutions it can be stated that with respect to the statistics, the existing domestic laws, and the international convention on this matter, and local cultures and traditions there is a need for a forensic pathology of child marriages. In addition, more progressive laws must be enacted, and families must be made aware of the negative consequences of child marriage. In fact, spreading awareness through religious references, the national media and other activists of this field can be highly effective. 
Topic Five: Inspecting the Rate of Child Marriage in Khorasan-Razavi Province

According to the official report of the women and family affairs vice presidency, with a record of 6759 marriages of under thirteen years old children, the Khorasan-Razavi province holds the first place in Iran in terms of child marriage.

In addition, while pointing to the high rates of marriage of child marriage in the Khorasan-Razavi province, the director general of the Civil Registry agency maintains that throughout the year 2017, a total of 53524 marriages were registered. In addition, in terms of the divorces registered for the age group of interest, it must be mentioned that throughout the year 2017, a total 16189 divorces were registered, 156 of which concerned younger than fifteen women. Although the amount of child marriage has declined compared to past years, it must be taken into account that these statistics only reflect the events that were formally registered.

Some believe that child marriage is an instance of child abuse, since early marriage leaves irreparable damages on children. The article 45 of the family support law emphasizes that the expediency of the children must be constantly adhered to by all courts, judicial references, and entire centers in contact with children and if a child under thirteen was forced to marry, the other spouse (adult) will be sentences to between 6 months to 2 years of imprisonment.

Sociologists believe that the most important reasons behind the high rate of child marriage in the province include economical and cultural poverty, substance abuse, tribal affairs, and immigration of alien nationals to the province. They also point out that families must be made aware that early marriage not only doesn't bring charm to the lives of their children, but even exposes their children to certain mental and physical problems as well as irreparable social and character-related damages.

Topic Six: On the Geographical Condition of Ismaeel-Abad; Statistical Investigation of Factors Effective on Child Marriage Word One: Geographical Condition of Ismaeel-Abad

The village of Ismaeel-Abad is a region located in the county of Toos, in the central part of the city of Mashhad, and its population is 3083 individuals.

Figure 1, The map of Ismaeel-Abad neighborhood in Mashhad

\section{Word Two: Statistical Investigation of factors Effective on Child Marriage in the Suburbs of Mashhad (Ismaeel-Abad neighborhood)}

in order to statistically investigate the factors effective on child marriage in the suburbs of Mashhad (Ismaeel-Abad neighborhood), a 20-item researcher made questionnaire wad codified which included four subscales namely as economic factors, cultural factors, effects of social attitude, and hope for a more desirable future. It is worthy of mentioning that the questionnaire's items were answered on a 5-point Likert scale.

The population of the present study was comprised of the entire residents of the suburbs of Mashhad (Ismaeel-Abad neighborhood), and the answers include expressing five types of views, each of which is given a unique code.

\section{Word Three: Investigating the Reliability of the Questionnaire using Cronbach's Alpha}

In the questionnaire of interest, items one to six were related to the economic factors, items seven to nine were related to the cultural factors, items ten to fifteen concerned the effect of social attitude, and the items sixteen to twenty were related to the subscale of hope for a more desirable future.

The Cronbach's Alpha value has been calculated using the SPSS software, and the following table presents the primary outputs. 
Table 1. results of calculating the Cronbach's alpha values

\begin{tabular}{|l|l|l|l|}
\hline Subscale & $\begin{array}{l}\text { Calculated } \\
\text { Cronbach's alpha }\end{array}$ & $\begin{array}{l}\text { Minimum Accepted } \\
\text { Cronbach's alpha }\end{array}$ & Status \\
\hline Economic factors & & Above 0.7 & Reliability rejected \\
\hline Cultural factors & & Above 0.7 & Reliability rejected \\
\hline $\begin{array}{l}\text { Effect of social } \\
\text { attitude }\end{array}$ & Above 0.7 & Reliability approved \\
\hline $\begin{array}{l}\text { Hope for a more } \\
\text { desirable future }\end{array}$ & Above 0.7 & Reliability rejected \\
\hline
\end{tabular}

As it can be seen in the above table, the reliability values for the three subscales of economic factors, cultural factors, and hope for a more desirable future are lower than 0.7, and so corrective measures have been taken to overcome these deficiencies.

As mentioned earlier, the items relating to the economic factors and child marriage subscale included items one to six. Among these items, the item 6 had the most significant role in decreasing the reliability of the questionnaire and so it was deleted, meaning that its effect was not included in the calculations. In addition, among the items seven to nine that were related to the cultural factors, the item 9 was deleted for the same reason, and was not included in the next calculations. Furthermore, the items sixteen to twenty entailed the subscale of hope for a more desirable future, of which the item 20 was deleted based on the previous reason, and was not included in next calculations.

After the changes were made, the SPSS software was once again used to calculated the Cronbach's alpha value of the questionnaire, and the results are displayed in the following table.

Table 2. results of recalculating the Cronbach's alpha values

\begin{tabular}{|l|l|l|l|}
\hline Subscale & $\begin{array}{l}\text { Calculated } \\
\text { Cronbach's alpha }\end{array}$ & $\begin{array}{l}\text { Minimum Accepted } \\
\text { Cronbach's alpha }\end{array}$ & Status \\
\hline Economic factors & & Above 0.7 & Reliability approved \\
\hline Cultural factors & & Above 0.7 & Reliability approved \\
\hline $\begin{array}{l}\text { Effect of social } \\
\text { attitude }\end{array}$ & Above 0.7 & Reliability approved \\
\hline $\begin{array}{l}\text { Hope for a more } \\
\text { desirable future }\end{array}$ & Above 0.7 & Reliability approved \\
\hline
\end{tabular}

\section{Word Four: Statistical Investigation of Variables Effective on Child Marriage}

As stated, the questions asked by the questionnaire covered the four areas of economic factors, cultural factors, effect of social attitude, and hope for a more desirable future. Results of the analyses are reported in the following table and diagram.

Table 3. Results of analysis of variables

\begin{tabular}{|l|l|l|l|l|l|}
\hline Interviewee & $\begin{array}{l}\text { Economic } \\
\text { factors }\end{array}$ & $\begin{array}{l}\text { Cultural } \\
\text { factors }\end{array}$ & $\begin{array}{l}\text { Effect of } \\
\text { social } \\
\text { attitude }\end{array}$ & $\begin{array}{l}\text { Hope for a } \\
\text { more } \\
\text { desirable } \\
\text { future }\end{array}$ & Total \\
\hline 1 & 2 & 3 & 4 & 5 & 3 \\
\hline
\end{tabular}

As it can be seen, the interviewees believe that economic factors and the effect of social attitude play the most significant roles in occurrence of early marriage.

Considering the fact that the residents of the area under investigation are not economically in a well shape, with the fathers of families mostly doing low paying jobs and the mothers being mere housekeepers, therefore the families' ability to flatten the needs of children is low, and many of the children may be deprived of higher education anyways. Lack of proper education in turn limits the job opportunities for the person and becomes another reason for poverty. 
On the other hand, undesirable economic conditions and dropouts caused by early marriage deprives the person from exploiting the new media of the current technological world. Illiteracy and low education in a society, especially among girls and women results in poor communications with media and social groups. Nowadays, communications are not limited to the neighborhood and school contacts; rather if a person fails to exploit this opportunity due to lack of proper education and literacy, he/she will not be able to make contacts and communicate in a dynamic society.

In addition, results show that interviewees also believe that the effect of social attitude is an important factor in early marriage. As reported by the investigation of the demographic features of the population of the present study, almost half of the interviewees' mothers were aged between thirty and forty years old, while the interviewees were all married and aged between twenty to thirty years old.

These statistics unveil the type of traditional beliefs in marriage. Results of investigating the statistics yielded for the questions of the present study regarding this field show that a large portion of the interviewees believe that in the area under investigation the girls usually marry at very young ages because it is believed that they may never be able to marry if they don't marry at young ages. This shows high effects of social attitude on the issue of early marriage of children.

\section{Conclusions}

By child marriage it is referred to a phenomenon where at least one of the spouses is under eighteen years old. Both words "child" and "marriage" have taken different definitions from society to society. The international society refers to people under eighteen years old as children whereas, different laws in different parts of the world maintain different definitions for "child". For instance, in Iran, law considers that people reach maturity before the age of eighteen.

The reasons for child marriage include: family relationships, discrimination (sexual inequality), controlling sexual relationships and maintaining the dignity of the family, economic factors, social factors, and cultural factors.

The present article has investigated the concept of child marriage from the perspective of Iran's legal system and jurisprudential basics, and the results have shown that with respect to the domain of necessity of growth for marriage in the views of jurists, the Holy Quran also uses the phrase "ultimate maturity", regarding which interpreters do not hold a united opinion, some believing that it relates to nocturnal emission and puberty while others believe it stresses out mental maturity. Some interpretations even maintain that the proper "ultimate maturity" age is thirty years.

In the view of Imamia jurists, growth must be determined through testing which maybe largely different between different social, domestic, and personal conditions. For testing, one must not rely on the results of on test rep, rather, the testing must be repeated until it is made clear that growth has taken place and the ability to manage affairs and properties has surfaced.

The present study has also investigated the most important factors promoting the spread of child marriage, and the results manifested that that the highest rate of child marriage in Iran is associated to the Khorasan-Razavi province. And in this regard, it must, be added that the city of Mashhad is surrounded by several suburban neighborhoods in which the rates of child marriage are extremely high. There are villages in the area where girls are mostly married when they reach seventh grade at school.

In an attempt to express solutions for mitigation of the rate of child marriage it can be stated that fighting poverty, spreading awareness among families and especially among parents, making parents aware of their parental responsibilities against their children, empowering the youth, recognition of children's capabilities and capacities, reviewing the laws, amending the cultural procedures of marriage, and recognizing the necessity of mental maturity for marriage and persuading mothers towards making their maternal role more vivid, are among the resolutions that can be suggested for preventing underage marriages.

Ultimately, field investigation of the causes of child marriage in the Ismaeel-Abad neighborhood of Mashhad shows that economic factors and social attitude are the most important factors promoting early marriage. 


\section{Suggestions}

It is suggested to try and provide a logical explanation of causes, consequences, and positive and negative effects of different marriage ages, and propose solutions to adjust the situation through establishing analysis programs as well as criticizing social issues of the youth in presence of experts. In addition, it is suggested to invite youths who have married before the age of eighteen so that they would directly express their experiences.

Another suggestion would be to make the people aware of the essential concepts and definitions of marriage. Because some people's lack of knowledge and proper understanding of marriage, may cause them to be totally unaware of the negative effects of early marriage on the mental health and physical well-being and fertility as well.

It is also suggested to make people aware of their rights and duties regarding their spouse, as well as improving their familiarity with the responsibilities they must hold after marriage. Because the results of similar previous studies show that most of child spouses do not have a proper awareness of their rights and duties because of their lack of knowledge.

\section{References}

Agha Bigloui, Abbas and Kazem Rasoulzadeh Tabatabai, Hassan Mousavi Chelek. (2001). Child Abuse, Tehran, Avand Danesh.

Davis, Mike. (2004). Planet of Slums, (Urban Involution and the Informal Proletariat), New Left Review, No. 26.

global policy Action. London: Published by IPPF; 2007. p.7-20. Available

global policy Action. London: Published by IPPF; 2007. p.7-20. Available

Gruber, Denis, et al. (2005). "Living and Working in Slums of Mumbai", Internet-Fassung, April, Otto-von-Guericke-Universität Magdeburg.

Islamic Republic News Agency. (2006). child of a spouse; Dual laws and culture building, news code: 83467966, dated 19/6/1398.

Lotfi, Razieh. (2010). Health Consequences of Early Marriage in Women, Islamic Azad University, Astara Branch, Journal of Women and Health, Volume 1, Number 2.

Marriage of girls at a young age The current situation and dimensions of the issue. (2018). Research Center of the Islamic Consultative Assembly, Deputy of Socio-Cultural Research Office: Cultural Studies.

Mehrizi, Mehdi. (1997). "Jurisprudential Treatises 1 Puberty of Girls", Islamic Propaganda Office Publishing Center, Vol, 8.

Mohaghegh Damad, Seyed Mostafa. (2003). "Jurisprudential study of family law", Islamic Sciences Publishing Center, tenth edition.

Najafi, Mohammad Hassan. (2015). "The jewel of the word in the explanation of Islamic law", Tehran, Islamic Library, the seventh edition.

Radio and TV news. (2018). child marriage, an unpleasant phenomenon in Khorasan Razavi, news code: 2300537 Publication date: 9/21/1397.

Shokouhi, Hossein. (1975). Suburbs of Tabriz, Research Institute of Humanities and Social Sciences, University of Tabriz.

Tabatabai, Seyyed Mohammad Hussein. (2012). "Al-Mizan in the interpretation of the Qur'an", Beirut, Scientific Foundation for Publications, second edition.

Tusi, Abi Al-Jaafar Muhammad Ibn Al-Hassan. (1409). "Al-Tabyan", Islamic Media School, First Edition.

Tusi, Abi Al-Jaafar Muhammad Ibn Al-Hassan. (1417). AH, "Al-Khalaf", Qom, Islamic Publishing Institute, First Edition.

Valaei, Issa. (2005). "Explanatory Dictionary of Terms of Principles", Tehran, Ney Publishing, Fourth Edition.

Articles 1-2, 12, 19, 24, 34-36, 28-29.

at: http://www.unfpa.org/sites/default/files/pub-pdf.

at: http://www.unfpa.org/sites/default/files/pub-pdf. 
Tamizi, A., \& Sheykholeslami, A.

Propósitos y Representaciones

May. 2021, Vol. 9, SPE(3), e1121

http://dx.doi.org/10.20511/pyr2021.v9nSPE3.1121 